\title{
KEBIJ AKAN FORMULASI KEKERASAN SEKSUAL TERHADAP ISTRI (MARITAL RAPE) BERBASIS KEADILAN GENDER DI INDONESIA
}

\author{
Aldila Arumita Sari', R.B. Sularto2 \\ Program Studi Magister Ilmu Hukum Universitas Diponegoro \\ Fakultas Hukum Universitas Diponegoro \\ J I. Imam Bardjo, S.H. No. 1-3, Kampus Peleburan, Semarang 50241 \\ aldilamita47@gmail.com
}

\begin{abstract}
Indonesian National Commission for Women in 2017 issued a report of 172 (totaling seventy two) cases of Marital Rape Sex. Marital Rape is defined as an act of sexual violence against a wife which leads to acts of rape, causing no sexual coercion. From the results of the author's research, the Criminal Code (KUHP) has not been explicitly regulated. In the Criminal Code it is only like rape outside a sacred bond or marriage. This can be seen as a gender bias because the wife does not have the right to get sexual violence from her husband. The PKDRT Law is used in connection with rape in the family, but the imposition is not a specification of the victim. In the Law the provisions of the victims of a person who lives in a household are subject to the same sanctions except children because there is a weighting of $1 / 3$ in the Criminal Code. Then it is necessary to reform the criminal law of Marital Rape's criminal act itself. Making legal conception can be done using a legal approach in other countries that regulate this Marital Rape. In preparing and printing the work of the author using the Normative J uridical Research Methodology.

Keywords: Formulation Policy, Marital Rape, Gender J ustice
\end{abstract}

\begin{abstract}
ABSTRAK
Komnas Perempuan Indonesia pada tahun 2017 mengeluarkan laporan terdapat 172 (seratus tujuh puluh dua) kasus mengenai Marital Rape. Marital Rape diartikan sebagai tindakan kekerasan seksual terhadap istri yang mengarah pada tindakan pemerkosaan, sebab terdapat unsur-unsur pemaksaan seksual. Dari hasil penelitian penulis, Kitab Undang-undang Hukum Pidana (KUHP) belum mengatur secara eksplisit. Dalam KUHP hanya mengenal pemerkosaan di luar ikatan suci atau perkawinan. Hal ini terlihat bias gender karena istri tidak mempunyai hak apabila mendapatkan kekerasan seksual dari suami. UU PKDRT mengatur terkait tindak pidana pemerkosaan dalam keluarga, namun penjatuhan sanksi tidak terdapat spesifikasi korban. Dalam Undang-Undang tersebut diatur korbannya seseorang yang tinggal dalam rumah tangga penjatuhan sanksinya sama kecuali anak karena ada pemberatan 1/3 dalam KUHP. Maka perlu adanya pembaharuan hukum pidana mengenai tindak pidana Marital Rape itu sendiri. Pembuatan konsepsi hukum dapat dilakukan dengan menggunakan pendekatan perbandingan hukum di negara-negara lain yang mengatur tentang Marital Rape ini. Dalam penyusunan dan penulisan karya ilmiah ini penulis menggunakan Metodologi Penelitian Yuridis Normatif.
\end{abstract}

Kata kunci: Keadilan Gender; Kebijakan Formulasi; Marital Rape.

\footnotetext{
${ }^{1}$ Mahasiswa Program Studi Magister IImu Hukum Universitas Diponegoro

2 Dosen Program Studi Magister IImu Hukum Universitas Diponegoro
} 
Jurnal Pembangunan Hukum Indonesia

Volume 1, Nomor 1, Tahun 2019
Program Studi Magister IImu Hukum Fakultas Hukum Universitas Diponegoro

\section{A. PENDAHULUAN}

Hukum di suatu negara berbeda-beda. Setiap negara memiliki aturan hukum sendiri-sendiri untuk mewujudkan keadaan aman tentram dan sejahtera.

Penggunaan upaya hukum, termasuk hukum pidana, sebagai salah satu upaya untuk mengatasi masalah sosial termasuk dalah bidang kebijakan penegakan hukum.(Arief, 2010)

Meminimalisir bahkan menghilangkan perbuatan pidana merupakan salah satu tugas suatu hukum di negara tersebut.

Menurut catatan tahunan (catahu) 2018 datadata yang terkumpul yang berkaitan dengan kekerasan terhadap perempuan (KtP) yang paling menonjol sama seperti tahun sebelumnya adalah KDRT/RP (ranah personal) yang mencapai angka $71 \%$ (9.609). Ranah pribadi paling banyak dilaporkan dan tidak sedikit diantaranya mengalami kekerasan seksual. Kekerasan seksual menjadi terbanyak kedua yang dilaporkan, dan menunjukkan rumah dan relasi pribadi belum menjadi tempat yang aman bagi perempuan. Dari 2.969 jumlah kasus terdapat 172 kasus mengenai marital rape. Karena negara Indonesia masih kental budaya patriarki sehingga istri enggan melapor. ( Catatan Tahunan Kekerasan Terhadap Perempuan Komnas Perempuan 2018)

Upaya penanganan kekerasan terhadap perempuan dan anak terus dilakukan baik oleh kelembagaan formal (pemerintah) maupun kelembagaan informal seperti LSM maupun Organisasi Masyarakat lainnya. Namun, hal yang menjadi permasalahan adalah terjadinya kesenjangan antara ketentuan-ketentuan yang diatur dalam undang-undang dengan realitas yang terjadi di masyarakat.

Faktor kendala dalam proses penegakan hukum kekerasan terhadap perempuan dan anak diakibatkan oleh dua faktor, yaitu tidak adanya laporan masyarakat (unreported) yang akan menghambat efektivitas proses penegakan hukum serta apabila laporan masyarakat tidak mendapatkan penyelesaian secara tuntas (unsolved) dari aparat penegak hukum akan menimbulkan ketidakpercayaan masyarakat terhadap proses penegakan hukum tersebut. (Chilmiati \& Sularto, 2014)

Pembatasan-pembatasan peran perempuan oleh budaya patriarki membuat perempuan terdiskriminasi. Akibatnya, munculnya berbagai masalah sosial yang mendiskriminasikan kebebasan perempuan. Indonesia adalah negara hukum, namun kenyataannya payung hukum sendiri belum mampu mengakomodasi berbagai permasalahan sosial tersebut. Penyebabnya, karena anggapan ranah perempuan masih dianggap terlalu domestik. Sehingga penegakan hukum pun masih cukup lemah dan tidak adil gender.

Seperti apa yang telah di tegaskan di atas masih banyaknya kasus marital rape yang khususnya dilakukan terhadap istri, bahwa problem marital rape adalah problem kekerasan seksual terhadap istri yang mengarah pada tindakan pemerkosaan, sebab terdapat unsur-unsur pemaksaan seksual. Dan ini berdampak yang cukup buruk terhadap istri baik 
Jurnal Pembangunan Hukum Indonesia

Volume 1, Nomor 1, Tahun 2019
Program Studi Magister Ilmu Hukum

Fakultas Hukum Universitas Diponegoro secara fisik maupun secara psikis maka seharusnnya mendapat perlindungan baik dari masyarakat maupun dari aparat pemerintah yang terkait. Kita ketahui belum adanya pengaturan mengenai permasalahan marital rape di Indonesia secara jelas. Maka perlu adanya pembaharuan hukum pidana mengenai marital rape itu sendiri. Berkaitan dengan pembaruan hukum pidana tersebut, Barda Nawawi Arief menyatakan: Makna dan hakikat pembaruan hukum pidana berkaitan erat dengan latar belakang dan urgensi diadakannya pembaruan hukum pidana itu sendiri. Latar belakang dan urgensi diadakannya pembaruan hukum pidana dapat ditinjau dari aspek sosiopolitik, sosiofilosofis, sosiokultural, atau dari berbagai aspek kebijakan (khususnya kebijakan sosial, kebijakan kriminal dan kebijakan penegakan hukum). (Arief, 2011)

Tidak adanya pengaturan kekerasan seksual dalam rumah tangga di dalam KUHP. Pengaturan mengenai kekerasan seksual dalam rumah tangga di Indonesia terdapat pada Undang-Undang Penghapusan Kekerasan Dalam Rumah Tangga terdapat pengaturan mengenai kekerasan seksual dalam rumah tangga dalam Pasal 8 dan sanksi pidana nya pada Pasal 46. Pasal 8 masih sangat luas dikarenakan korban yang dimaksud dalam Pasal tersebut adalah semua orang yang menetap di rumah tersebut seperti anak, anak angkat, suami/istri, mertua ipar dan pembantu rumah tangga, hal ini terlihat belum adanya spesifikasi korban dalam menentukan penjatuhan sanksi pidana. Harus adanya spesifikasi korban yang berdampak pada penjatuhan sanksi pidana. Seperti spesifikasi terhadap korban istri (marital rape) menurut teori nurture yang dengan adanya konstruksi sosiak menempatkan perempuan stratanya lebih rendah dari laki-laki maka dari itu adanya perkawinan tersebut dan masih melekatnya budaya Indonesia yang patriarki yang menempatkan istri sebagai stratanya lebih rendah dari suami. Hubungan seksual antara suami istri di anggap wajar yang di lakukan berulang-ulang selama ikatan perkawinan terjadi sehingga pemerkosaan yang dilakukan oleh suami termasuk ranah domestik rumah tangga maka masyarakat luas melihat hal tersebut pertengkaran yang wajar bukan suatu kejahatan. Hal ini berbeda dengan ikatan antara majikan dan pembantu dan juga ipar dan mertua. Perbedaannya tidak terikat dalam ikatan perkawinan jadi perbuatan tersebut dinilai tidak wajar bagi masyarakat umum dan tidak lebih rentan di lakukan secara berulang-ulang berbeda apabila dalam ikatan perkawinan yang dinilai hubungan suami istri adalah kewajiban bagi setiap pasangan yang menikah. Apabila korbannya anak sudah ada pengaturan secara khusus mengenai hal tersebut.

Menurut Satjipto Rahardjo prinsip hukum adalah untuk manusia dan bukan sebaliknya, dan hukum tidak untuk diri sendiri, melainkan untuk sesuatu yang lebih luas, yaitu harga diri manusia, kebahagiaan, kesejahterahan dan kemuliaan manusia. (Rahardjo, 2006)

Identifikasi masalah yang penulis akan bahas adalah berkaitan dengan kekerasan seksual dalam 
Jurnal Pembangunan Hukum Indonesia

Volume 1, Nomor 1, Tahun 2019
Program Studi Magister Ilmu Hukum Fakultas Hukum Universitas Diponegoro rumah tangga yang spesifikasi korbannya adalah istri (marital rape). Berdasarkan latar belakang tersebut, maka rumusan masalahnya mengenai Apakah kebijakan formulasi marital rape di indonesia bias gender, bagaimana kebijakan formulasi marital rape yang berkeadilan gender. Tujuan dari penelitian ini adalah mengetahui apakah kebijakan di Indonesia sudah tepat dan tidak bias gender dan merumuskan bagaimana suatu kebijakan yang tepat dan berkeadilan gender dalam tindak pidana marital rape.

\section{B. PEMBAHASAN}

\section{Kebijakan Formulasi Marital Rape Di Indonesia}

Tindak pidana perkosaan adalah salah satu bentuk kekerasan terhadap perempuan yang merupakan contoh kerentanan posisi perempuan, utamanya terhadap kepentingan seksual laki- laki. Perhatian dan perlindungan terhadap kepentingan korban tindak pidana perkosaan baik melalui proses peradilan pidana maupun melalui sarana kepedulian sosial tertentu merupakan bagian mutlak yang perlu dipertimbangkan dalam kebijakan hukum pidana dan kebijakan- kebijakan sosial, baik oleh lembaga eksekutif, legislatif dan yudikatif maupun lembagalembaga sosial lainnya. (Wedani, 2015)

Marital rape adalah istri yang beroleh tindak kekerasan seksual suami dalam sebuah perkawinan atau rumah tangga. Dengan demikian, marital rape merupakan tindak kekerasan atau pemaksaan yang dilakukan oleh suami terhadap istri untuk melakukan aktivitas seksual tanpa mempertimbangkan kondisi istri.( Maria, 2007)
Menurut Mansor Faqih gender related violence kekerasan yang disebabkan oleh bias gender. Kekerasan atas nama gender ini seringkali di sebabkan oleh ketidaksetaraan kekuatan yang ada dalam masyarakat atau keluarga. Beberapa contoh kekerasan gender di antaranya : pemerkosaan perempuan, tindakan kekerasan fisik dalam rumah tangga (domestic violence).( Fanani,2014)

Bias gender itu berkorelasi dengan kekerasan dalam rumah tangga. Dari beberapa kajian literatur, istilah bias gender merujuk pada pandangan tentang maskulinisme dan feminimisme bahwa laki-laki dan perempuan memiliki perbedaan mengenai diri atau identitas mereka masing-masing. Teori individualis mengatakan bahwa perilaku agresi dan kekerasan dipelajari dari karakteristik maskulin seorang laki-laki. Dengan melakukan kekerasan dalam rumah tangga laki-laki merasa menunjukan jati dirinya sebagai lakilaki sejati. (Asmarany,2008) Berbicara mengenai marital rape di Indonesia, berarti juga berbicara hukum yang berlaku di Indonesia.

Prinsip-prinsip yang harus di muat dalam suatu aturan hukum yang bersepektif Ham dan keadilan serta kesetaraan gender, yaitu: (Komisi Anti Kekerasan Terhadap Perempuan,2014)

Yaitu, persamaan substantive (substantive Equality), ${ }^{3}$ Non-Diskriminasi, ${ }^{4}$ Integritas tubuh (Body

3Menekankan pentingnya kesetaraan gender secara substansial bukan lagi sekedar formalitas.

${ }^{4}$ Tidak ada pembedaan berdasarkan jenis kelamin dalam setiap kebijakan dan tindakan negara termasuk dalam pemenuhan hak korban. 
Jurnal Pembangunan Hukum Indonesia

Volume 1, Nomor 1, Tahun 2019
Program Studi Magister Ilmu Hukum

Fakultas Hukum Universitas Diponegoro
Integegritu), ${ }^{5}$ Kedirian (Persohood), ${ }^{6}$ Keberagaman (Diversity). ${ }^{7}$

Berikut penulis paparkan mengenai hukum yang berlaku di Indonesia.

a. Kitab Undang-undang

Pasal 285 sampai 287 adalah pengaturan pemaksaan bersetubuh dalam luar perkawinan dan pasal 287 juga membahas tentang korban persetubuhan di bawah umur. Pasal 288 membahas mengenai pemaksaan persetubuhan di dalam perkawian namun di jelaskan apabila korban di bawah umur dan menyebab kan luka-luka. Dalam KUHP tindak ada pengaturan mengenai pemerkosaan atau pemaksaan persetubuhan dalam perkawinan secara luas hanya di bahas apabila korban di bawah umur dan menyebabkan luka-luka. Karena pengaturan pemaksaan persetubuhan hanya di atur di luar perkawinan, maka pemaksaan hubungan di dalam perkawinan tidak di pidana. Bagi KUHP, yang disebut pemerkosaan hanyalah pemaksaan hubungan seksual pada perempuan bukan istri. Karena hal tersebut maka istri tidak bisa mengadukan sang suami ke pengadilan dengan

\footnotetext{
5 Bentuk-bentuk perlindungan ham atas tubuh manusia yang secara fisik dan psikologis harus di hormati sesuai martabat kemanusiaan, hak utama integritas,kebebasan dan kesetaraan status semua manusia.

6 Setiap individu mempunyai hak menentukan dirinya sendiri dan memperoleh perlakuan secara individual dan bersifat khusus, sesuai kebutuhan dirinya sendiri sebagai subjek hukum untuk didengar diikuti keinginannya, ditumbuhkan pengetahuannya tentang hak dan kewajiban di dalam hukum.

${ }^{7}$ Asas ini memberi makna tentang pengakuan dan pengukuhan bahwa pelaksanaan hak asasi manusia harus dijalankan dengan tetap menghormati dan mengharagi realitas keberagaman dan perbedaan atas nama budaya, agama, status sosial, status pendidikan, ekonomi dan orientasi seksual.
}

alasan pemerkosaan. Jikapun ada, perkaranya akan dianggap dan di proses sebagai penganiyaan bukan pemerkosaan.

Berbagai produk hukum di Indonesia, secara substansi, selalu didominasi dan lebih berpihak pada kepentingan laki-laki. Standar yang digunakan untuk mengatakan: apakah suatu perbuatan melanggar hukum atau tidak, juga standar laki-laki. Seakanakan, jenis kelamin hukum di Indonesia adalah lakilaki. Keberpihakan hukum terhadap laki-laki itu, sangat terlihat dalam Hukum Positif (hukum yang berlaku) di Indonesia.(Harahap, 2003)

b. Undang-Undang Nomer 23 Tahun 2004 Tentang Penghapusan Kekersan Dalam Rumah Tangga (UUPKDRT)

Undang-Undang Nomor 23 Tahun 2004 Tentang Penghapusan Kekerasan Dalam Rumah Tangga (UUPKDRT) membahas mengenai pengaturan kekerasan dalam rumah tangga adalah pemaksaan hubungan seksual yang di lakukan terhahap orang yang tinggal dalam lingkup rumah tangga tersebut "pemaksaan hubungan seksual yang dilakukan terhadap orang yang menetap dalam lingkup rumah tangga" dan sudah ada pengaturan pemidanaanya. namun pengaturan pasal ini sangat luas sekali karena pasal tersebut tidak mengklasifikasikan korbannya anak, istri-suami, atau pembantu rumah tangga. Hanya tujuanlah sebagai pembeda klasifikasi sebuah perbuatan tersebut. Untuk pasal 8a tidak ada tujuan hanya ada pemaksaan persetubuhan saja sedangkan $8 b$ mempunyai tujuan "tujuan komersial dan/atau tujuan 
Jurnal Pembangunan Hukum Indonesia

Volume 1, Nomor 1, Tahun 2019
Program Studi Magister Ilmu Hukum Fakultas Hukum Universitas Diponegoro tertentu." Hanya hal ini sebagai klasifikasi pembeda untuk pemidanaan nya. Klasifikasi korban dalam penjatuhan pemidanaan di perundang-undangan ini tidak ada. Penanganan permasalahan kekerasan seksual yang korbannya anak, istri, saudara dan pekerja rumah tangga sangat berbeda-beda maka dari itu, menurut saya, pengaturan ini kurang melihat terhadap korban dari pemaksaan hubungan seksual yang dilakukan terhadap orang yang menetap dalam lingkup rumah tangga tersebut. Budaya patriarki dan teori nurture ini sendiri yang membuat posisi perempuan di bawah laki-laki, maka perempuan memiliki ketergantungan terhadap laki-laki. Alasan penulis mempunyai ide adanya spesifiksai terhadap kekerasan seksual yang korban nya istri dan pelakunya suami, dengan adanya suatu perkawinan antara suami istri tersebut dan budaya Indonesia yang masih kental dengan patriarki yang di analisis dengan teori nurture menepatkan istri sebagai pelayan kebutuhan suami sehingga kekerasan seksual yang di lakukan oleh suami ke istri di anggap sesuatu yang wajar dan perbuatan tersebut rentan di lakukan secara berulang-ulang selama ikatan perkawinan terjadi.

c. Putusan Pengadilan Marital Rape Di Indonesia

Penulis mengelompokkan Marital Rape termasuk manifestasi ketidakadilan gender termasuk dalam "gender related violence". Menurut Mansor Faqih gender related violence kekerasan yang disebabkan oleh bias gender. Kekerasan atas nama gender ini seringkali di sebabkan oleh ketidaksetaraan kekuatan yang ada dalam masyarakat atau keluarga. Beberapa contoh kekerasan gender di antaranya: pemerkosaan perempuan, tindakan kekerasan fisik dalam rumah tangga (domestic violence). (Fanani ,2014) Menurut penulis adanya marital rape karena dominannya kekuasaan laki-laki dari pada perempuan. Karena melihat dari budaya Indonesia sendriri marital rape membuat seolah-olah istri pelayan suami atau milik suami ketika sudah menikah karena menepatkan laki-laki yang sudah menikah drajatnya di atas perempuan yang sudah menikah.

Putusan pengadilan adalah tahap aplikasi dari tahap-tahap penegakan hukum pidana, dalam membuat putusan seorang hakim harus melihat dasar hukum yang berlaku. Putusan Nomor: 912/Pid/B/2011/PN.Bgl dan Putusan Nomor: 899/ Pid.Sus/2014/PN Dps hakim dalam membuat putusan marital rape menggunakan pengaturan marital rape terdapat Undang-undang No.23 tahun 2004 Tentang Penghapusan Kekerasan Dalam Rumah Tangga.

Menurut penulis dalam kasus marital rape ini harus adanya pemberatan penjatuhan pidana karena dalam budaya Indonesia yang patriarki ini menepatkan suami sebagai kepala rumah tangga yang seharusnya melindungi. Adanya pemberatan penjatuhan pidana ini bertujuan membuka masyarakat bahwa marital rape termasuk kejahatan dan perbuatan tersebut salah di lakukan. Apalagi karena budaya patriarki ini membuat perempuan yang sudah menikah menjadi ketergantungan terhadap suami maka rentan marital rape tersebut di 
Jurnal Pembangunan Hukum Indonesia

Volume 1, Nomor 1, Tahun 2019
Program Studi Magister IImu Hukum

Fakultas Hukum Universitas Diponegoro lakukan secara berulang-ulang hal ini yang penulis tekankan perlunya adanya pemberatan. Dalam perspektif kriminologi tentang maslah kejahatan hal ini masuk dalam Macrotheories.

Macrotheories adalah teori-teori yang menjelaskan kejahatan dipandang dari segi struktur sosial dan dampaknya. Dalam hal ini melihat tepatnya karena dalam konteks hubungan social,lakilaki dan perempuan tidak menepati kedudukan setara dala hirarki social, terdapat bentuk diskriminasi structural yang terungkap dalam hubungan kerja, dan yang lebih penting dalam lingkup kerja.( Kristiani, 2014)

Teori macrotheories di dukung dengan pengelompokan yang penulis telah di jelaskan di atas yaitu marital rape termasuk "gender related violence". Marital rape di sebabkan karena budaya patriarki yang menganggap apabila suami istri menikah maka, istri atau perempuan tersebut menjadi milik suami atau istri menjadi pelayan suami. Konsep patriarki menempatkan perempuan sebagai bumi yang memberi. Keangkuahan patriaki menyimbolkan alam sebagai ibu pertiwi. Menempatkan ibu dalam hal ini perempuan yang selalu memberi tanpa dirawat kembali atau tidak ada timbal baliknya.

Menurut penulis, marital rape adalah perbuatan yang berlanjut, dengan adanya budaya patriarki di Indonesia menempatkan bahwa istri adalah pelayan suami, dan di perkuat dengan Pasal 285 KUHP ini mensyiratkan bahwa istri tidak dapat melapor apabila terjadi kekerasan seksual yang di lakukan oleh suami. Penulis dapat menyimpulkan bahwa marital rape adalah perbuatan berlanjut. Bias gender dalam putusan pengadilan di atas adalah ketika pertimbangan hakim tidak menempatkan marital rape sebagai perbuatan rentan yang terjadi berulang atau perbuatan berlanjut, maka dalam putusan tersebut hakim tidak menjunctokan penjatuhan sanksi marital rape dengan KUHP Pasal 65 mengenai perbuatan berlanjut sehingga penjatuhan sanksi pidana tersebut dapat di perberat.

\section{Kebijakan Formulasi Marital rape di Beberapa Negara}

\section{a. Pengaturan Marital Rape Di Philipina}

Republic Act No. 8353 September 30, 1997 An

Act Expanding The Definition of The Crime Of Rape, Reclassifying The Same As A Crime Against Persons, Amending For The Purpose Act No. 3815, As Amended, Otherwise Known As The Revised Penal Code, And For Other Purposes. Pasal 226-B pelaku pemerkosaan hukumannya adalah "Reclusión perpetua".8 Dalam keadaan tertentu di atas di sebutkan dapat menjadi hukuman mati.

Hukum Filipina, tahanan dilarang hidup dari memegang jabatan politik, jadi pelaku pemerkosaan tidak boleh memegang jabatan politik. Lalu apabila pelaku terkena HIV dan juga pelaku menyebabkan cacat fisik mendapat hukuman mati. Pasal 226-C tersebut menjelaskan apabila suami sebagai pelaku dan istri sebagai korban. apabila suami mendapatkan pengampunan dari istri, maka pidananya di hapuskan. Dan apabila pernikahan batal demi

\footnotetext{
${ }^{8}$ Tahanan dilarang hidup dengan memegang jabatan politik.
} 
Jurnal Pembangunan Hukum Indonesia

Volume 1, Nomor 1, Tahun 2019
Program Studi Magister IImu Hukum

Fakultas Hukum Universitas Diponegoro hukum, maka pemidanaan tersebut tidak dapat di hapuskan.

Kebijakan tersebut termasuk keadilan gender karena menerapkan prinsip non diskriminatif, sama di mata hukum, jadi pemerkosaan yang di lakukan di luar perkawinan dan di dalam perkawinan dapat di jatuhi pidana hal ini termasuk pemenuhan hak warga negaranya.integritas tubuh, kedirian, keberagaman dan kewajiban negara dari kenakan penjatuhan pemidanaan terhadap suami yang melakukan marital rape. Apabila cacat fisik atau suami HIV di jatuhkan hukuman mati hal tersebut terlihat prinsip integritas tubuh.

\section{b. Pengaturan Marital Rape Di Malaysia}

Penal Code Of Malaysia Merujuk pada pasal 375 KUHP, sebelum amandemen pada tahun 1989 kode itu diam tentang pembebasan perkawinan dalam perkosaan. Yang paling dekat untuk menyentuh masalah itu adalah pengecualiannya,

Malaysia pemerkosaan suami terhadap istri atau yang di sebut "Marital Rape" ini tidak ada. Di anggap pemerkosaan apabila sudah ada keputusan pemisahan dari pengadilan. Sedangkan untuk muslim di malaysia setelah talak 3 kali yang dalam masa iddah walaupun belum ada putusan dari pengadilan apabila suami memaksa hubungan suami istri maka, dapat di katakan pemerkosaan atau kekerasan seksual.( Aziz, 2004)

Kebijakan tersebut termasuk keadilan gender karena menerapkan prinsip non diskriminatif sama di mata hukum, jadi pemerkosaan yang di lakukan di luar perkawinan dan di dalam perkawinan dapat di jatuhi pidana hal ini termasuk pemenuhan hak warga negaranya, persamaan substantive, integritas tubuh, bentuk-bentuk perlindungan ham atas tubuh manusia, kedirian,kebebasan individu menentukan dirinya sendiri karena di ketahuhi manusia di lahirkan merdeka keberagaman dan kewajiban negara dari kenakan penjatuhan pemidanaan terhadap suami yang melakukan pemaksaan hubungan suami istri pada masa idah.

\section{Pengaturan Marital Rape Di Korea}

Penal Code korea mengatur pemerkosaan secara umum Pasal 297 SAMPAI 298 sedangkan, Act On Special Cases Concerning The Punishment, Etc. Of Sexual Crimes. Chapter I General Provisions ini pengaturan secara khususnya di lihat dari penjatuhan pemidanaannya lebih besar penjatuhan pemidanaan dalam Special Cases Concerning The Punishment, Etc. Of Sexual Crimes. Chapter I General Provisions. Pada Pasal 5 "Rape,etc. through abuse of consanguineous or Marital Relationship :" Yang artinya adalah Pemerkosaan, melalui penyalahgunaan Hubungan kerabat atau Hubungan Pernikahan, jadi pengaturan ini mengenai pemerkosaan yang dalam ranah hubungan pertalian seperti perkawinan dan kerabat atau saudara.

Setelah penulis menganalisis Undang-udang di negara lain yang mengatur mengenai marital rape ini penulis mempunyai ide pembaharuan dalam pengaturan marital rape di Indonesia. Yaitu ada spesifikasi korban istri dalam kekerasan seksual dalam rumah tangga yang berada di Undang-Undang No.23 Tahun 2004 Tentang Penghapusan Kekerasan 
Jurnal Pembangunan Hukum Indonesia

Volume 1, Nomor 1, Tahun 2019
Program Studi Magister Ilmu Hukum Fakultas Hukum Universitas Diponegoro
Dalam Rumah Tangga, dilihat dari korbannya karena seorang istri lebih rentan di lakukan berulang-ulang dan juga karena kontruksi social dan buaya patriarki di indonesi seolah-olah istri pelayan suami termasuk urusan seksual tersebut jadi, seolah-olah istri tidak mempunyai hak untuk menolak dan pemaksaan hubungan seksual tersebut seperti yang penulis katakan di atas lebih rentan di lakukan secara berulang-ulang, serta apabila suami menjadi pemimpin dalam tumah tangga seharusnya melindungi tidak menyakiti. Berbeda dengan putusan pengadilan di atas yang menurut penulis kurang adil.

Penulis mempunyai ide pembaharuan yang lain itu, apabila di ketahui suami mempunyai penyakit HIV memaksa istri melakukan hubungan seksual tanpa memberitahu istri maka, suami di perberat lagi penjatuhan pidananya karena dapat menular terhadap sang istri dan membahayakan sang istri, terlebih lagi apabila sang istri hamil atau sedang menyusui, anak tersebut akan tertular. Hal ini dapat merusak generasi penerus angsa yang masih mempunyai masa depan yang panjang.

Putusan pidana pengadilan dalam sebagai alasan pengajuan perceraian, dalam kasus ini penulis mempunyai ide apabila penjatuhan pidana mengenai marital rape korban ingin melakukan perceraian dengan pelaku atau suami korban hanya perlu mengisi formulir dari pengadilan negeri, lalu formulis tersebut di transfer terhadap panitera yang menangani perceraian di pengadilan negeri maupun pengadilan agama, jadi korban tidak perlu melakukan sidang perceraian ulang dan mengikuti prosedur yang di tetapkan pengadilan, korban melakukan perceraian melalui jalan pintas. Jalan pintas yang di maksud hanya pengalihan berkas terhadap panitera, korban mengisi formulir apakah ingin bercerai atau tidak apabila ingin bercerai panitera menstransfer berkas non muslim panitera pidana akan menstransfer berkas ke panitera perdata untuk mengeluarkan putusan cerai, jika yang bercerai muslim panitrea pidana pengadilan negeri menstranfer berkas terhadap panitera pengadilan agama. Hal tersebut mengurangi beban dan trauma korban dan dapat membantu pemulihan korban dari trumanya.

Di Malaysia di atur mengenai umat muslim tentang iddah. Di Indonesia juga dapat di atur karena mengingan negara kita mempunyai 6 agama yang di akui, dan mayoritas adalah agama islam. Dapat di letakan di sana pengaturan mengenai iddah. Dalam umat muslim iddah adalah masa tunggu setelah perceraian dan dalam umat muslim juga apabila suami melakukan pemaksaan hubungan seksual terhadap istri dalam di kategorikan marital rape, karena belum adanya putusan dari pengadilan namun secara muslim mereka telah bercerai.

Paparan di atas adalalah ide pembaharuan hukum pidana mengenai marital rape hukum selalu berkembang mengikuti perkembangan tingkah laku masyarakat, maka dari itu pembaharuan hukum sangat perlu di karenakan pola pikir dan masa masyarakat selalu berjalan tidak berhenti begitu pula dengan hukum harus berkembang seiring 
Jurnal Pembangunan Hukum Indonesia

Volume 1, Nomor 1, Tahun 2019
Program Studi Magister Ilmu Hukum

Fakultas Hukum Universitas Diponegoro perkembangan kehidupan masyarakat untuk mencapai keamanan dan kesejahterahan bersama.

\section{SIMPULAN}

Hubungan seksual dalam suatu ikatan perkawinan membuat marital rape termasuk asing di kalangan masyarakat. Kitab Undang-undang Hukum Pidana (KUHP) merupakan salah satu dasar hukum di Indonesia yang mengatur hukum pidana materiil, sedangkan pengaturan marital rape belum ada di dalam KUHP, dalam KUHP hanya mengenal pemerkosaan di luar ikatan suci yang disebut perkawinan hal ini terlihat bias gender dalam KUHP pengaturan marital rape karena istri tidak mempunyai hak apabila mendapatkan kekerasan seksual dari suami. Dalam UU PKDRT namun dalam perundangundangan ini penjatuhan sanksi tidak ada spesifikasi korban, jadi korbannya seseorang yang tinggal dalam rumah tangga penjatuhan sanksinya sama kecuali anak karena ada pemberatan 1/3 dalam KUHP. Menurut penulis spesifikasi korban menentukan penjatuhan sanksi pidana. Seperti contoh apabila istri apabila mendapatkan kekerasan seksual dari suami karena budaya patriarki menepatkan istri lebih rendah dan sebagai pelayan suami, maka kekerasan dalam rumah tangga ini rentan di lakukan berulangulang. Ini menjelaskan bahwa UUPKDRT bias gender. Putusan Pengadilan Negeri Bangil, Pasuruan dan Pengadilan Negeri Denpasar, Bali engenai marital rape ini menurut penulis bias gender karena tidak men-Jucto-kan terhadap Pasal 65 KUHP Perbuatan berlanjut karena menurut penulis marital rape tersebut termasuk pkejahatan yang rentan di lakukan secara berulang-ulang.

Pengaturan marital rape ini di tempatkan dalam klasifikasi penganiyayaan bukan pemerkosaan, penganiyayaan sangat berbeda perlakuan pelaku terhadap korban. Penjatuhan sanksi pidana penganiyayaan dan pemerkosaan juga lebih ringan, Konsep KUHP bias gender. Pada Juli 2018 Rancangan Konsep KUHP mempunyai rancangan mengenai kekerasan seksual sama dengan UUPKDRT, sedangkan Indonesia berlaku lex spesialis derogate legi generalis yang menggunakan aturan khusus dan mengesampingkan aturan umum, apabila sama bunyinya tetap menggunakan aturan khusus yaitu UU PKDRT Penulis membuat perbandingan perundangundangan mengenai marital rape dengan negara Thailand, Malaysia dan Korea sehingga penulis mempunyai ide pembaharuan pidana dalam rumusan kedua adalah pemberatan pemidanaan terhadap marital rape. Pemberatan pidana apabila pelaku terjangkit HIV, masa idah atau proses menunggu perceraian apabila ada kekerasan seksual dapat di golongkan marital rape dan juga perceraian tanpa melalui proses perceraian seperti ketentuan dalam Peraturan Pemerintah Republik Indonesia Nomor 9 Tahun 1975 Tentang Pelaksanaan Undang-Undang Nomor 1 Tahun 1974 Tentang Perkawinan apabila alasan perceraian adanya marital rape. 


\section{DAFTAR PUSTAKA}

\section{Buku}

Fanani, Ahmad Z. (2014). Berfilsafat Dalam Putusan

Hakim (Teori Dan Praktik). Bandung: CV. Mandar Maju.

Maria, M. (2007). Marital Rape, Kekerasan Suami

Terhadap Istri. Yogyakarta: Pustaka Pesantren.

Arief, Barda N. (2011). Bunga Rampai Kebijakan Hukum Pidana. Jakarta: Kencana

Arief, Barda N. (2010). Kebijakan Legislatif Aalam Penanggulangan Kejahatan Dengan Pidana Penjara. Yogyakarta: Genta Publishing.

Komisi Anti Kekerasan Terhadap Perempuan. (2014). Mewujudkan Perlindungan Hak-hak Perempuan Korban dalam Kebijakan: Himpuan Kertas Posisi dan Kajian diri Berbagai Kebijakan Tahun 2010-2013. J akarta: Ghalia Indonesia.

Rahardjo, S. (2006). Membedah Hukum Progresif. Jakarta: Kompas

\section{J urnal}

Asmarany, Anugriaty I. (2008). Bias Gender Sebagai Prediktor Kekerasan Dalam Rumah Tangga. J urnal Psikologi Vol 35, (No. 1) ,p. 4.

Kristiani, Ni Made D. (2014). Kejahatan Kekerasan Seksual (Perkosaan) Ditinjau Dari Perspektif Kriminologi. Jurnal Magister Udayana,Vol.7 (No.3) , p.376.

Harahap, Z. (2003). Menggugat Hukum yang Bias Gender. J urnal Hukum, vol 10, (No.22) ,p. 90 Aziz, Norazlina Bt A. (2004). Marital Rape : A View
On Malaysia Law And Common Law, Jurnal Akademik Uitm Cawangan J ohor, vol.4,(no.1), p.74.

Wedani, Ni Putu A.M., \& Dananjaya, Nyoman S. (2015). Perlindungan Korban Tindak Pidana Perkosaan Selama Proses Peradilan Pidana. J urnal Magister Hukum Udayana Vol 3,( No 2) ,p.3.

Chilmiati, N., \& Sularto, RB. (2014). Kebijakan Advokasi Terhadap Perempuan Dan Anak Berbasis Perlindungan Korban Kekerasan. J urnal Law Reform Vol.9, (no.2), p. 111. 